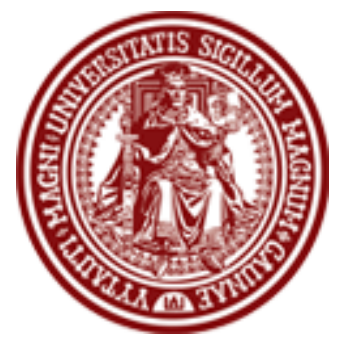

BALTIC JOURNAL OF LAW \& POLITICS

VOLUME 5, NUMBER 2 (2012)

ISSN 2029-0454

http://www.versita.com/science/law/bjlp

Cit.: Baltic Journal of Law \& Politics 5:2 (2012): 65-80

DOI: $10.2478 / \mathrm{v} 10076-012-0011-1$

\title{
THE EU PRACTICE OF HORIZONTAL AGREEMENT ASSESSMENT \\ IN ACCORDANCE WITH THE RULE OF PROVIDING DE MINIMIS EXEMPTION
}

\author{
Andrius Puksas \\ Doctoral Candidate \\ Mykolas Romeris University, Faculty of Law (Lithuania) \\ Contact information \\ Address: Ateities str. 20, Vilnius LT-08303, Lithuania \\ Phone: (+370 5) 2714542 \\ E-mail address: andrius_puksas@mruni.eu; andrius.puksas@gmail.com
}

Received: July 2, 2012; reviews: 2; accepted: December 7, 2012.

\section{ABSTRACT}

This article analyses the practice of horizontal agreement assessment in accordance with its impact on competition. The following research is based on analysis of scientific literature, current provisions of European Union and national legal acts, as well as official positions of the European Commission (hereinafter - EC) and national authorities.

The current inconsistent practice of horizontal agreement assessment within the EU creates space for multiple interpretations. It is important to emphasize that the assessment rules provided in legal acts are, by their nature, only guidelines.

More flexibility, but also more obscurity, in the assessment process bring with it the possibility for institutions to independently set priorities (for instance 'priority rule' in Lithuanian legislation, i.e. in the Articles 18.2.3. and 24.2.8 of the Law on Competition of the Republic of Lithuania, Official Gazette, 2012, no. 42-2041).

The article analyses current regulation of horizontal agreement assessments in accordance with minor impact on competition. 


\section{KEYWORDS}

Horizontal agreement, de minimis exception, impact on competition, hardcore restraints 


\section{INTRODUCTION}

According to the Article 101(1) of the Treaty on the functioning of the European Union (hereinafter - TFEU), as incompatible with the internal market, all agreements shall be prohibited between undertakings, decisions by associations of undertakings and concerted practices which may affect trade between Member States and which have as their object or effect the prevention, restriction or distortion of competition within the internal market. ${ }^{1}$ Further, it provides an exemplary list of agreements which should be prohibited in accordance with the main rule. Nevertheless, agreements considered harmful for competition can be declared to have an insignificant impact, thus becoming unprohibited (i.e. legal) in accordance with Article 101(1) TFEU.

Legislators provide some criteria which can help in determining if the agreements between economic units are of minor importance. TFEU is the main legal act directly applied in EU member states. In 1969 the European Court of Justice (hereinafter - ECJ) created a precedent by applying an exemption from the 'prohibition rule' which currently is a tool provided by Article 101(1) TFEU (the content of the exemption will be disclosed further). The ECJ practice was followed by de minimis notices (the most recent adopted by the EC in 2001) ${ }^{2}$. However, despite that basics for the application of de minimis exemption were set, Notice and its provisions are not obligatory. The legal literature provides brief references to the legislation where quantitative criteria (market thresholds) are determined, such as in the work of Alison Jones and Brenda Sufrin ${ }^{3}$, Richard Whish ${ }^{4}$. Foreign authors prefer to analyze Article 101 TFEU and to give references to current de minimis Notice. Often they just mention the existence of exemption, such as in the work of Martin A. Carree, Andrea Günster, and Maarten Pieter Schinkel. ${ }^{5}$ Almost the same can be said about Lithuanian legal specialists. Daivis Švirinas ${ }^{6}$ and Irmantas Norkus $^{7}$ partly touch on the regulation of agreements of minor importance in their

\footnotetext{
${ }^{1}$ Consolidated Version of the Treaty on the Functioning of the European Union, Official Gazette (2008, no. C 115/47).

${ }^{2}$ Notice (December 22, 2001) on Agreements of Minor Importance which do not Appreciably Restrict Competition under Article 81(1) of the Treaty Establishing the European Community (de minimis), European Commission, Official Gazette (2001, no. 368/07).

${ }^{3}$ Alison Jones and Brenda Sufrin, EU Competition Law. Text, Cases, and Materials, $4^{\text {th }}$ edition (New York: Oxford University Press, 2011), p. 171-177.

${ }^{4}$ Richard Whish, Competition Law, $7^{\text {th }}$ edition (New York: Oxford University Press, 2012).

5 Martin A. Carree, Andrea Guenster, and Maarten Pieter Schinkel, "European Antitrust Policy 19572004: An Analysis of Competition Decisions," Review of Industrial Organization 36(2010): 6.

6 Daivis Švirinas, The Regulation of Vertical Agreements in Competition Law, Doctoral dissertation (Vilnius: Social sciences (01 S), 2004), p. 62-64.

7 Irmantas Norkus, Prohibited Agreements in Accordance with EC Competition Law, Doctoral dissertation (Vilnius: Social sciences (01 S), 2001).
} 
doctoral research. Daivis Švirinas ${ }^{8}$ analyzed the possibility of applying de minimis exemption for agreements containing recommended resale price. The possibility to apply de minimis exemption for agreement containing hardcore restraints is a subject of frequent discussion ${ }^{9}$.

This article analyzes the problematic issues of agreement assessment and its proper accordance with de minimis exemption. It is problematic not only if an agreement contains hardcore restraints (from the so called blacklist). Another problem is the inconsequence of judicial practice in assessing such agreements. Specifically in Lithuania, even more obscurity appeared after 'priority rule' was introduced, which allowed the Competition Council of the Republic of Lithuania (hereinafter - Competition Council) to declare some of the cases as insignificant and terminate the related discussions. Is the Competition Council creating new de minimis provisions? This article seeks to bring clarity to these issues.

The assessment results determine the agreement's validity and the consequences of its maintenance or abolishment; that is why it is so important to assess agreements properly. Therefore the aim of the research is to analyze and evaluate the current process of horizontal agreement assessments in accordance with de minimis doctrine and to give proposals concerning current assessment scheme(s).

\section{HORIZONTAL AGREEMENTS THAT HAVE ONLY MINOR IMPORTANCE ON COMPETITION}

The institution of agreements of minor importance for competition in European competition law appeared four decades ago. The basis for them is the European Court of Justice (hereinafter - ECJ) decision in the Völk $v$ Vervaecke case in 1969:

Consequently an agreement falls outside the prohibition in Article 85 when it has only an insignificant effect on the markets, taking into account the weak position which the persons concerned have on the market of the product in question. Thus an exclusive dealing agreement, even with absolute territorial protection, may, having regard to the weak position of the persons concerned on the market in the products in question in the area covered by the absolute protection, escape the prohibition laid down in Article 85(1). ${ }^{10}$

\footnotetext{
${ }^{8}$ Daivis Švirinas, "The Peculiarities of the Assessment of the Use of Recommended Resale Prices under Article 81 of the European Community Treaty," Social Sciences Studies No. 1(5) (2010).

${ }_{9}^{9}$ Andrius Puksas, "On the Potential to Apply De Minimis Exemption for Agreements Containing Hardcore Restraints: European Union Practice," Baltic Journal of Law \& Politics 5:1 (2012).

${ }_{10}$ Völk $v$ Vervaecke, European Court of Justice $(1969$, no. 5/69).
} 
The current case provides an example of exemption applied for an agreement containing a hardcore restraint ${ }^{11}$ (restriction by the object - absolute territorial protection for the distributor). Despite the fact that ECJ applied de minimis exemption, such possibility has never been stated in any further de minimis Notices. In comparison, de minimis exemption was not applied in the 'Miller' case ${ }^{12}$, although the case met the guidelines stated in the Notice.

Nevertheless, with the Völk $v$ Vervaecke case, ECJ made its contribution to the appearance of de minimis exemption. The agreements of parties which do not have 'market power' despite their negative impact on competition do not distort competition significantly. As a result there is no need to prohibit them ${ }^{13}$. The spirit of the Völk $v$ Vervaecke case outcome was transferred to de minimis Notices ${ }^{14}$. On the one hand it is a non-obligatory technical document and, on the other hand, the provisions of de minimis Notice are useful during the agreement assessment process $^{15}$.

Later de minimis rule was reflected in other legal acts. For instance, the recommendations which were in force till January 14, 2011 stated that prohibition is inapplicable for agreements which are not capable of restricting the competition considerably by object or effect ${ }^{16}$. The substance of agreements having an insignificant impact on competition stayed the same after horizontal co-operation agreement guidelines came into force on January $14,2011^{17}$.

EU legal acts do not provide definition for agreements of minor importance. However, the definition is provided by the features mentioned above ${ }^{18}$ : agreements of minor importance - agreements between two or more economic units which cannot distort competition and (or) trade significantly. The same can also be said about the content of the Lithuanian legislation ${ }^{19}$, including a lack of an 'agreements of minor importance' definition. However, one feature is specific: the distortion of trade is not 'in focus' during the national assessment process.

\footnotetext{
${ }^{11}$ Andrius Puksas, supra note 9.

12 Miller International Schallplatten $\mathrm{GmbH} v$ Commission of the European Communities, European Court of Justice $(1978$, no. 19/77).

${ }^{13}$ It should be noted that the numeration of Articles was changed several times. Currently de minimis exemption is applied by Article 101 TFEU.

${ }_{14}^{14}$ De minimis Notices: 1970, 1977, 1986, 1994 (amendment to 1986), 1997 and 2001.

15 Also seeking to avoid confusion with references to actual provisions reader should bear in mind that further mentioned Article 81 of Treaty establishing the European Economic Community and Article 101 TFEU have the same content.

${ }_{16}$ Notice (January 6, 2001) "Guidelines on the Applicability of Article 81 of the EC Treaty to Horizontal Cooperation Agreements", European Commission, Official Gazette (2001, C 3/02 (expired)), par. 15.

17 Communication (January 14, 2011) on Guidelines on the Applicability of Article 101 of the Treaty on the Functioning of the European Union to Horizontal Co-operation Agreements, European Commission, Official Gazette (2011, no. C 11/01).

${ }_{18}$ Notice (December 22, 2001), supra note 2.

${ }^{19}$ Resolution no. 1S-172 (December 9, 2004) on Approval of Requirements and Conditions in Respect of Agreements of Minor Importance which do not Appreciably Restrict Competition, Competition Council of the Republic of Lithuania, Official Gazette (2004, no. 181-6732).
} 
The biggest concern during the process of individual agreement assessment is the evaluation and determination of its effect on competition. The process cannot be carried out only by formal comparison with the quantitative criteria from legal acts. The official position of Competition Council is clear: if the agreement does not pass the requirements of insignificant impact, it cannot be considered to have minor importance ${ }^{20}$. The detailed analysis of national practice ${ }^{21}$ allows us to state that the main reason not to apply exemption from the Resolution concerning agreements on minor importance is hardcore restraints.

\section{THE SCHEME OF AGREEMENT ASSESSMENT IN ACCORDANCE WITH THE SIGNIFICANCE OF ITS IMPACT ON COMPETITION}

The assessment of agreements between economic units in accordance with the significance of their impact on competition is conducted according to the following scheme:

- determine if the agreement does not have hardcore restraints. If not:

- define the relevant market where the agreement parties carry out activities;

- determine the agreement parties' share in the relevant market. In case of horizontal agreements common market share of all parties together should be determined.

The scheme is based on assessment criteria provided by EU legal acts ${ }^{22}$. The order of procedures is also derived from legislation. When determination that agreement does not contain hardcore restraints has been reached, it is appropriate to take further actions - e.g. define the relevant market where the parties carry out activities and determine their share. Why does the assessment have to be carried out in this order? The agreements containing hardcore restraints are prohibited per se. As a rule, after determining hardcore restraints further assessment according to this scheme is abolished. The order of the second and the third stages cannot be changed - defining the relevant market is the first thing to do.

This scheme should also be applicable even in the case of hardcore restraints.

\footnotetext{
${ }^{20}$ Resolution no. 2S-29 (November 22, 2010), Competition Council of the Republic of Lithuania, Official Gazette (2010, no. 90(1)-1071), p. 6.1.

${ }^{21}$ Resolution no. 2S-14 (June 11, 2009), Competition Council of the Republic of Lithuania, Official Gazette (2009, no. 47(1)-611), p. 5.2.

${ }^{22}$ Notice (December 22, 2001), supra note 2; Communication (January 14, 2011), supra note 17.
} 


\subsection{HARDCORE RESTRAINTS AS A CONDITION WITHIN WHICH MARKET THRESHOLDS ARE NOT APPLIED}

There is no doubt about the importance of market thresholds criteria. However, according to current EU regulation it should be taken into account only when hardcore restraints have not been determined. Hardcore restraints are qualitative criteria assessing the agreement in accordance with its impact on competition. In other words, agreements should not contain any hardcore restraints in order to apply the exemption.

Certainly there is a downside and the de minimis Notice is criticized for its weak points ${ }^{23}$. For example, if two kiosks decide to fix prices it does not automatically mean that their decision will affect the competition significantly. Customers and clients are free to choose other kiosks to satisfy their needs. Nevertheless the $11^{\text {th }}$ point in current de minimis Notice provides us with a series of restraints which altogether can be defined as the blacklist:

- $\quad$ price fixing when selling the products to third parties;

- limitation of output or sales;

- $\quad$ allocation of markets or customers.

The hardcore restraints from the EU legal act were also transferred to national legislation. Competition Council Resolution Nr. 1S-172 item 7 provides the blacklist for horizontal agreements. It states that the quantitative 10 percent market share criterion is inapplicable for horizontal agreements:

- to directly or indirectly fix prices for certain goods;

- $\quad$ to share the product market on a territorial basis, according to groups of buyers or suppliers or in any other way;

- to fix certain product production or sale volume.

There is no question that any assessment will result in determining the agreement as having a negative impact on competition as long as any hardcore restraints arise. But why are the ones listed above considered to be more dangerous than others? EU Guidelines of January 14, 2011 provides a partial answer:

Restrictions of competition by object are those that by their very nature have the potential to restrict competition within the meaning of Article 101(1). It is not necessary to examine the actual or potential effects of an agreement on the market once its anti-competitive object has been established. ${ }^{24}$

\footnotetext{
23 Massimo Motta, Competition Policy: Theory and Practice (New York: Cambridge University Press, 2004).

${ }^{24}$ Communication (January 14, 2011), supra note 17, par. 24 and 160.
} 
Hardcore restraints directly affect the result of competition process (for instance price growth, declining of production rates), thus agreements containing hardcore restraints automatically fall into the Article 101(1) TFEU limitations and because of their impact on competition the assessment process is skipped. As a rule even if the effect on competition is minor, parties of such agreements cannot expect the exemption to be applied. The provision concerning price fixing, limiting output or sharing markets or customers in legal acts appeared with respect to longstanding practice: "Infringements of that kind, particularly in the case of horizontal cartels, are classified by the case law as 'particularly serious' since they involve direct interference with the essential parameters of competition on the market" ${ }^{25}$. Agreements containing such restraints are understood as obviously harmful for competition and are prohibited per se, so there is no need to prove their negative impact on competition.

The goal of agreements containing hardcore restraints is to restrict competition. It is presumed that parties initially are seeking to cause harmful consequences. In order to apply Article 101(1) TFEU it is enough to determine that parties had prevention, restriction or distortion of competition as their goal. The actual impact is not important. ${ }^{26}$ Despite the fact that such an agreement could also have a positive impact, it is presumed that the harm they cause is bigger than provided benefits. ${ }^{27}$

Do agreements containing hardcore restraints always have a significant impact on competition? According to King's College (London) law professor Richard Whish, the European Commission could not take action against agreements containing hardcore restraints when parties' parts in the relevant market do not exceed the thresholds ${ }^{28}$. If such restraints are determined we cannot talk about market shares which are analogical for agreements that do not contain hardcore restraints. According to current regulations the barrier is 10 percent of aggregate share (more information in paragraph 2.3.). If hardcore restraints are determined, the borders should be stricter (for example 1 percent of aggregate share). Economists can provide the official border as a presumption; however, there is a possibility it may not be applicable for every agreement - an individual case might still need a separate evaluation. It is obvious that parties that have a very small part in the relevant market cannot distort competition significantly. It is highly recommended to apply de minimis exemption for them as well. Without question, the quantitative criteria have to be flexible. National courts in Germany, Spain and

\footnotetext{
${ }^{25}$ BPB $v$ Commission, The Court of First Instance (2008, no. C 209 (Case T-53/03)), par. 270.

${ }^{26}$ Ibid., par. 4.

27 Competition (May 4, 2010): Commission Consults on New Regime for Assessment of Horizontal Cooperation Agreements, European Commission (2010, MEMO/10/163), par. 1.

${ }^{28}$ Richard Whish, supra note 4.
} 
the legislators in the Netherlands have already taken some steps towards rehabilitation of hardcore restraints ${ }^{29}$. If the parties of the agreement are very small there is no risk to distort competition significantly.

\subsection{DEFINING A RELEVANT MARKET}

If an agreement is concluded between two or more economic units which do not contain hardcore restraints, the assessment process should begin by defining a relevant market. "Market definition is a tool to identify and define the boundaries of competition between firms." ${ }^{30}$ The definition of a relevant market has to be as accurate as possible.

Relevant market covers product market and geographic market ${ }^{31}$. Why is it necessary to define a relevant market? It allows us to distinguish concrete product and geographic markets where it is appropriate to complete the assessment. Parties have their field of activity which is separated from other markets. In the case of a more extensive market, the probability is higher that the thresholds of parties in the market are smaller. It also means a higher probability to apply de minimis exemption.

To define the relevant market, these stages are to be taken:

- definition of product market (analysis of demand and supply replaceability);

- definition of geographic market (demand and supply replaceability are analyzed).

When defining relevant market it is necessary to assess the demand and supply replaceability ${ }^{32}$. The following factors are important to take into account:

- the possibility for economic units to adapt changes raised by agreements;

- the possibility for customers to change the product affected by the agreement with a substitute;

- $\quad$ the possibility for other economic units to enter the market.

When assessing the demand, replaceability products that users consider as proper substitutes (according to their features, usage and price) are determined. When assessing supply replaceability, other suppliers' reaction to changes made by the agreement should be determined. The market is defined as narrow, since the

\footnotetext{
${ }^{29}$ Andrius Puksas, supra note 9: 46-69.

30 Notice (December 9, 1997) on the Definition of Relevant Market for the Purposes of Community Competition Law, European Commission, Official Gazette (1997, no. 372/03), par. 2.

31 Ibid., par. 7-8.

32 Resolution no. 17 (February 24, 2000) Concerning Explanations of the Competition Council on the Definition of the Relevant Market, Competition Council of the Republic of Lithuania, Official Gazette (2000, no. 19-487), items 7-12.
} 
possibilities of subjects are slim to choose or to react to the changes raised by the agreements. If there is a variety of product substitutes and after individual assessment a possibility to react to changes without high expense still exists, the relevant market is defined as extensive.

The formulation of point 7 (a) of de minimis Notice is extremely important: agreements which affect trade do not appreciably restrict competition "if the aggregate market share held by the parties to the agreement does not exceed 10 $\%$ on any of the relevant markets affected by the agreement". Competition Council of the Republic of Lithuania Resolution No. 1S-172 gives us such wording: "the aggregate share of the relevant market" (item 4.1.). It is obvious that an agreement can affect not only one relevant market. All markets affected by the agreement have to be assessed. Agreements can affect a couple product and geographic markets. For instance, if barriers for product substitution exist they can be attributed to different markets. In some cases where it is important for the secondary product (supplement to a primary product) to be compatible with the primary one, it can be considered as a primary and secondary product. ${ }^{33}$ To make a clear distinction between the two, here is an example: spare car parts are a secondary or supplementary product in the context of the car which is the primary one. Even one agreement between economic units can have an impact on several markets. For instance, an agreement between companies that produce and sell home appliances can have consequences for markets of vacuum cleaners, refrigerators, etc. Those home appliances cannot be substitutes for one another, which means there are different relevant markets.

The proper definition (not too wide but also not too narrow) of a relevant market plays an important role in assessing agreements. According to Simon Bishop and Mike Walker, relevant market definition helps to "understand the various ways in which products do or might compete with one another" ${ }^{34}$. Criteria which were provided above in this section are important for defining a relevant market.

\subsection{THE CRITERIA OF AGREEMENT PARTIES' MARKET THRESHOLDS}

EU and national legal acts provide quantitative criteria or the criteria of market thresholds of the agreement parties which allow us to carry out agreement assessment process in accordance with the significance of its impact on competition. The final results of assessment should be:

\footnotetext{
33 Ibid., item 27.

34 Simon Bishop and Mike Walker, The Economics of EC Competition Law: Concepts, Application and Measurement, $3^{\text {rd }}$ edition (London: Sweet \& Maxwell and Thomson Reuters, 2010), p. 219.
} 
- determination if the agreement distorts competition;

- determination if the agreement should be prohibited in case if it distorts competition.

Contrary to prior legal acts, the de minimis Notice ${ }^{35}$ covers agreements which distort competition significantly.

Setting reference criteria and comparing specific agreement with those criteria would result in the possibility of avoiding a complicated individual assessment and saving that institution's means. The presumptions embodied in legal acts can be denied by providing serious reason(s). It could be data proving that individual agreement has significant impact on competition which cannot fulfill the requirements to apply de minimis exemption. According the current EU regulation the quantitative criteria are current and relevant when it is determined that no hardcore restraints have been detected.

The European Commission took into account the practice of ECJ and in the recommendational character legal act provided criteria which are advised for use during the assessment process. The criteria are stricter for horizontal agreements ${ }^{36}$.

According to the settled case-law of the Court of Justice of the European Union, in order to assess whether an agreement has an anti-competitive object, regard must be had to the content of the agreement, the objectives it seeks to attain, and the economic and legal context of which it forms part. ${ }^{37}$

Given the fact that each single agreement has an individual impact on competition, institutions carrying out assessment should determine the quantity of the effect. The quantitative criteria are the approach to achieve this goal.

There are no doubts that the agreement's effect on competition depends on its parties position in the market. Greater power in the market means higher risk that the agreement can be more harmful. The reverse situation also exists (lower power - lower risk - less harmful). It is more important to horizontal agreements which parties carry out activities at the same level. The quantitative criteria are based on presumptions which can be denied after the individual assessment.

During the assessment of horizontal agreement in accordance with Article 101 TFEU it is necessary to determine shares of the parties in the relevant market. Paragraph $7(a)$ in the current de minimis Notice states that there is no appreciable restriction on competition "if the aggregate market share held by the parties to the agreement does not exceed $10 \%$ on any of the relevant markets affected by the agreement, where the agreement is made between undertakings which are actual

\footnotetext{
35 Notice (December 22, 2001), supra note 2.

36 Ibid.

37 Communication (January 14, 2011), supra note 17, par. 25.
} 
or potential competitors on any of these markets. ${ }^{138}$ This quantitative criterion or 10 percent barrier for horizontal agreements (agreements between competitors) is a presumption.

An analogic 10 percent barrier is also provided for mixed agreements because they contain features of horizontal agreements. In comparison, for vertical agreements the barrier provided is 15 percent. But it is wrong to carry out an assessment process only according to the percentage, because the basis of determination is not the same. Attention should be paid to other important criteria. The barrier for horizontal and mixed agreements is 10 percent of the aggregate market share, for vertical it is a 15 percent barrier for each participant of the agreement. "However, to the extent that vertical agreements, for example, distribution agreements, are concluded between competitors, the effects of the agreement on the market and the possible competition problems can be similar to horizontal agreements. Therefore, vertical agreements between competitors fall under these guidelines. ${ }^{\prime 39}$ Such agreements are considered mixed or agreements where it is difficult to determine whether they are horizontal or vertical. If there are doubts, the barrier of 10 percent should be used; the same for horizontal agreements. The same rules and criteria give reason to doubt the practice of dividing mixed agreements. Is it meaningful to have a separate category? Different assessment rules for various kinds of agreements are induced by their different dangerousness, manufacturing and distribution level; it is presumed that parties of the same level have a more significant impact on competition.

The definition of appreciability covers both qualitative (for instance, fact of hardcore restraints) and quantitative (for example, market shares) criteria.

In order to define the parties' shares in the relevant market, we need to use: data about selling rates received from the parties; information on relevant market from other subjects; statistical analysis of the market; and other important data for assessment. ${ }^{40}$ The most recent statistical data is important in order to determine changes and new tendencies in the market. Sometimes, when situations are similar, decisions made in previous cases can also be useful.

It is obvious that exceeding the provided 10 percent barrier cannot be a reason not to apply de minimis exemption unconditionally. The opposite situation is possible as well - even parties having less than 10 percent of the market share can conclude an agreement which will affect competition significantly. It is impossible to create universal assessment rules because each agreement has a different impact on competition. Point 2 in de minimis Notice states: "Negative definition of

\footnotetext{
${ }^{38}$ Notice (December 22, 2001), supra note 2.

${ }^{39}$ Communication (January 14, 2011), supra note 17, par. 12.

${ }^{40}$ Resolution no. 17 (February 24, 2000), supra note 32, items 30-32.
} 
appreciability does not imply that agreements between undertakings which exceed the thresholds set out in this notice appreciably restrict competition". ${ }^{41}$ The Lithuanian de minimis legal act ${ }^{42}$ does not contain analogical provisions despite the fact that it is wrong to state that quantitative criteria cannot be inflexible. The Competition Council should not be bounded by numbers only. Exclusion of such provision can be explained by the fact that in each case quantitative criteria are a part of presumptions which can be denied. However, the Competition Council declares that Lithuanian competition law should be interpreted in the light of EU competition law $^{43}$, therefore the quantitative criteria applied in Lithuania are not absolute. The practice of EU courts is based on conception of individual agreement assessment. According to court decisions it is necessary to take into account the economic context of the specific case study during the assessment ${ }^{44}$. Provision concerning the possibility to carry out individual agreement assessment is suggested for inclusion in the new edition of the national legal act. The provision could state: "Criteria provided by the Resolution do not exclude the possibility that agreements which parties' shares in the market exceed the provided borders restrict competition significantly".

Despite Resolution No. 1S-172 and its criteria, the Competition Council is free to set 'new de minimis provisions' - Law on Competition provides the 'priority rule $^{\prime 45}$. This means that the Competition Council independently decides whether some facts are important to investigate or not. From one side such flexibility creates obscurity; however, it also allows justifying some agreements which do not distort competition significantly but formally should be prohibited.

One of the most important accents of assessment is the application of provisions from legal acts. The Competition Council transferred almost all the main provisions concerning agreements of minor importance from de minimis Notice to the Resolution ${ }^{46}$. Provisions of de minimis Notice are applicable if the agreement between the parties has an impact on competition and trade between the member states. For agreements between Lithuanian economic units which do not cross national relevant market and is defined by the territory of Republic of Lithuania national legal acts provisions are applicable. And what about the situation when de minimis provisions in the EU and Lithuanian legal act differ? This question is important because as a rule the Competition Council apply EU and national rules at

\footnotetext{
${ }^{41}$ Notice (December 22, 2001), supra note 2, point 2.

42 Resolution no. 1S-172 (December 9, 2004), supra note 19.

${ }^{43}$ For instance Resolution no. 2S-13 (June 9, 2011), Competition Council of the Republic of Lithuania, Official Gazette (2011, no. 48(1)-439); Resolution no. 2S-10 (May 12, 2011), Competition Council of the Republic of Lithuania, Official Gazette (2011, no. 39(1)-353).

${ }^{44}$ European Night Services v Commission, The Court of First Instance (1998 (Case T-374/94)), par. 136.

${ }^{45}$ Law on Competition of the Republic of Lithuania. Official Gazette, 2012, no. 42-2041, article 18.2.3., also 24.4.8.

${ }^{46}$ Resolution no. 1S-172 (December 9, 2004), supra note 19.
} 
the same time. Despite the harmonization process, opinions can differ (competition authorities are not bound by de minimis Notice, also 'priority rule' can be applied for some provisions).

\section{CONCLUSIONS AND PROPOSALS}

1. The de minimis Notice appeared as a reaction to the ECJ decision in Völk $v$ Vervaecke in 1969. This legal act provides guidelines for how to apply de minimis exemption. ECJ is not bound by the provisions of the de minimis Notice and in each case the decision can be different (for instance in 'Miller' case de minimis exemption was not applied although the facts met provisions stated in de minimis Notice).

2. Law on Competition of the Republic of Lithuania provides the 'priority rule'. According to it the Competition Council independently decides whether specific cases are important to investigate or not; therefore, this institution is free to form 'new de minimis provisions'. On the one hand such flexibility creates obscurity, and, on the other, it allows justifying some agreements which do not distort competition significantly but formally should be prohibited.

3. Not all agreements containing hardcore restraints have a significant impact on competition. In a case in which hardcore restraints are determined, the quantitative criteria (borders) applied should be stricter (for example 1 percent of aggregate share).

\section{BIBLIOGRAPHY}

1. Bishop, Simon, and Mike Walker. The Economics of EC Competition Law: Concepts, Application and Measurement. $3^{\text {rd }}$ edition. London: Sweet \& Maxwell and Thomson Reuters, 2010.

2. Carree, Martin A., Andrea Guenster, and Pieter Maarten Schinkel. "European Antitrust Policy 1957-2004: An Analysis of Competition Decisions." Review of Industrial Organization 36(2010).

3. Jones, Alison, and Brenda Sufrin. EU Competition Law. Text, Cases, and Materials. $4^{\text {th }}$ edition. New York: Oxford University Press, 2011.

4. Motta, Massimo. Competition Policy: Theory and Practice. New York: Cambridge University Press, 2004.

5. Norkus, Irmantas. Prohibited Agreements in Accordance with EC Competition Law. Doctoral dissertation. Vilnius: Social sciences (01 S), 2001.

6. Puksas, Andrius. "On the Potential to Apply De Minimis Exemption for Agreements Containing Hardcore Restraints: European Union Practice." Baltic Journal of Law \& Politics 5:1 (2012): 46-69. 
7. Švirinas, Daivis. "The Peculiarities of the Assessment of the Use of Recommended Resale Prices under Article 81 of the European Community Treaty." Social Sciences Studies No. 1(5) (2010): 219-236.

8. Švirinas, Daivis. The Regulation of Vertical Agreements in Competition Law. Doctoral dissertation. Vilnius: Social sciences (01 S), 2004.

9. Whish, Richard. Competition Law. $7^{\text {th }}$ edition. New York: Oxford University Press, 2012.

\section{LEGAL REFERENCES}

1. BPB $\vee$ Commission. The Court of First Instance. 2008, no. C 209 (Case T$53 / 03)$.

2. Communication (January 14, 2011) on Guidelines on the Applicability of Article 101 of the Treaty on the Functioning of the European Union to Horizontal Co-operation Agreements. European Commission. Official Gazette, 2011, no. C 11/01.

3. Competition (May 4, 2010): Commission Consults on New Regime for Assessment of Horizontal Co-operation Agreements. European Commission. 2010, MEMO/10/163.

4. Consolidated Version of the Treaty on the Functioning of the European Union. Official Gazette, 2008, no. C 115/47.

5. Draft "Guidelines (May 4, 2010) on the Applicability of Article 101 of the Treaty on the Functioning of the European Union to Horizontal Co-operation Agreements". European Commission. SEC (2010) 528/2.

6. European Night Services $v$ Commission. The Court of First Instance. 1998 (Case T-374/94).

7. Law on Competition of the Republic of Lithuania. Official Gazette, 2012, no. 42-2041.

8. Miller International Schallplatten $\mathrm{GmbH} v$ Commission of the European Communities (Case 19/77). European Court of Justice. 1978, ECR 131.

9. Notice (December 22, 2001) on Agreements of Minor Importance which do not Appreciably Restrict Competition under Article 81(1) of the Treaty Establishing the European Community (de minimis). European Commission. Official Gazette, 2001, no. 368/07.

10. Notice (December 9, 1997) on the Definition of Relevant Market for the Purposes of Community Competition Law. European Commission. Official Gazette, 1997, no. 372/03. 
11. Notice (January 6, 2001) "Guidelines on the applicability of Article 81 of the EC Treaty to Horizontal Cooperation Agreements". European Commission. Official Gazette, 2001, C 3/02 (expired).

12. Resolution no. 17 (February 24, 2000) Concerning Explanations of the Competition Council on the Definition of the Relevant Market. Competition Council of the Republic of Lithuania. Official Gazette, 2000, no. 19-487.

13. Resolution no. 1S-172 (December 9, 2004) on Approval of Requirements and Conditions in Respect of Agreements of Minor Importance which do not Appreciably Restrict Competition. Competition Council of the Republic of Lithuania. Official Gazette, 2004, no. 181-6732.

14. Resolution no. 2S-10 (May 12, 2011). Competition Council of the Republic of Lithuania. Official Gazette, 2011, no. 39(1)-353.

15. Resolution no. 2S-13 (June 9, 2011). Competition Council of the Republic of Lithuania. Official Gazette, 2011, no. 48(1)-439.

16. Resolution no. 2S-14 (June 11, 2009). Competition Council of the Republic of Lithuania. Official Gazette, 2009, no. 47(1)-611.

17. Resolution no. 2S-29 (November 22, 2010). Competition Council of the Republic of Lithuania. Official Gazette, 2010, no. 90(1)-1071.

18. Treaty Establishing the European Economic Community (EEC). 1957.

19. Völk $v$ Vervaecke. European Court of Justice. 1969, no. 5/69. 